\title{
Szociális szorongás és önértékelés: a „Félelem a negatív megítéléstől” (FÉLNE) kérdőív hazai adaptációja
}

\author{
Perczel-Forintos Dóra dr. - Kresznerits Szilvia \\ Semmelweis Egyetem, Általános Orvostudományi Kar, Klinikai Pszichológia Tanszék, Budapest
}

\begin{abstract}
Bevezetés: Noha a szociális szorongás a harmadik leggyakoribb pszichés megbetegedés, sokszor nem kerül felismerésre. Legfontosabb jellemzői az alacsony önértékelés, a magas szintű önkritika és félelem mások negatív megítélésétól. Nagyfokú komorbiditást mutat a hangulatzavarokkal, az alkoholfogyasztással és az evészavarokkal. Célkitüzés: A nemzetközileg legismertebb mérőeszköz, a Félelem a negatív megitéléstöl (FÉLNE) skála hazai adaptálása, belső és külső validitásvizsgálata.

Módszer: Résztvevők: 255 szorongásos, illetve hangulatzavarral diagnosztizált páciens töltötte ki a kérdốveket. Mérőeszközök: „Félelem a negatív megítéléstől” (FÉLNE) kérdőív 30, 12 és 8 itemes változat, Rosenberg Önértékelési Skála, Beck Szorongás Leltár, Szociális Kogníció kérdő́iv.

Eredmények: Mindhárom FÉLNE kérdőív erős belső validitással rendelkezik $(\alpha>0,83)$; az alacsony önértékeléssel, a negatív szociális kogníciókkal és az általános szorongással közepesen erős összefüggést mutat. A legrövidebb kérdőív a FÉLNE-8 validitása bizonyult a legerősebbnek a szociális fóbia elkülönítésére más pszichés megbetegedésektól. Köpetkeztetések: A FÉLNE-8 alkalmazása elősegítheti a számos betegség hátterét jelentő szociális szorongás gyors felismerését, a páciensek adekvát pszichoterápiás ellátás felé irányítását az egészségügyi ellátás bármely szintjén.

Orv Hetil. 2017; 158(22): 843-850.
\end{abstract}

Kulcsszavak: szociális szorongás, alacsony önértékelés, Félelem a negatív megítéléstől kérdőív - FÉLNE-8, pszichoterápia

\section{Social anxiety and self-esteem: Hungarian validation of the "Brief Fear of Negative Evaluation Scale - Straightforward Items"}

Introduction: Although social anxiety disorder (SAD) is the third most frequent emotional disorder with $13-15 \%$ prevalence rate, it remains unrecognized very often. Social phobia is associated with low self-esteem, high self-criticism and fear of negative evaluation by others. It shows high comorbidity with depression, alcoholism, drug addiction and eating disorders.

Aim: To adapt the widely used "Fear of Negative Evaluation" (FNE) social phobia questionnaire.

Method: Anxiety and mood disorder patients $(\mathrm{n}=255)$ completed the Fear of Negative Evaluation Scale $(30,12$ and 8 item-versions) as well as social cognition, anxiety and self-esteem questionnaires.

Results: All the three versions of the FNE have strong internal validity $(\alpha>0.83)$ and moderate significant correlation with low self-esteem, negative social cognitions and anxiety. The short 8 -item BFNE-S has the strongest disciminative value in differentiating patients with social phobia and with other emotional disorders.

Conclusions: The Hungarian version of the BFNE-S is an effective tool for the quick recognition of social phobia.

Keywords: social anxiety disorder (SAD), low self-esteem, Fear of Negative Evaluation Scale, BFNE-S, psychotherapy

Perczel-Forintos D, Kresznerits Sz. [Social anxiety and self-esteem: Hungarian validation of the "Brief Fear of Negative Evaluation Scale - Straightforward Items"]. Orv Hetil. 2017; 158(22): 843-850.

(Beérkezett: 2017. március 11.; elfogadva: 2017. április 12.) 


\section{Rövidítések}

BSZL = Beck Szorongás Leltár; FÉLNE-8 = Félelem a negatív megítéléstől kérdőív - 8 itemes változat (Brief Fear of Negative Evaluation Scale - Straightforward Items - BFNE-S); FÉLNE-12 = Félelem a negatív megítéléstől kérdőív 12 tételes változat (Brief Fear of Negative Evaluation Scale - BFNE); FÉLNE-30 = Félelem a negatív megítéléstől kérdőív - 30 tételes változat (Fear of Negative Evaluation Scale - FNE); RSES = Rosenberg Önértékelési Skála; SAD $=$ (social anxiety disorder) szociális szorongás zavar; SCQ = Szociális Kogníciók Kérdő́iv; SCQ_gy = negatív szociális kogníciók gyakorisága; SCQ_int $=$ negatív szociális kogníciók megélésének intenzitása; SCQ_kudarc = félelem a kudarctól (teljesítményhelyzetben); SCQ_negfél = félelem a negatív megítéléstôl; SCQ_negh = negatív hiedelmek az énről

Ma már egyértelmúnek túnik, hogy a szociális szorongás zavar (social anxiety disorder - SAD) a harmadik leggyakoribb pszichiátriai megbetegedés, aminél csak a major depresszió és az alkohollal kapcsolatos diagnózisok fordulnak elő többet. Élettartam-prevalenciája 12\% körül mozog, szemben a többi szorongásos zavarral: $6 \%$ a generalizált szorongás, $5 \%$ a pánikbetegség, $7 \%$ a PTSD és $2 \%$ az OCD élettartam-prevalenciája [1]. Talán nem véletlen, hogy korunkban épp ez a szorongásos zavar fordul elő leggyakrabban, hiszen a nagy teljesítmény és a perfekcionizmus társadalmilag magasra értékelt és nemritkán elvárt magatartásformák, amelyeknek stresszkeltő hatása vitathatatlan. A társas helyzetek hatására megjelenő distresszt nevezzük tehát szociális szorongásnak, amely a legújabb diagnosztikai rendszer, a DSM-5 definíciója szerint: „Észrevehetô és tartós félelem egy vagy több olyan szociális vagy elóadói teljesitményt igénylö helyzettöl, amelyben a személy mások lehetséges figyelmének van kitéve. Az ilyen helyzetbe kerülés majdnem minden esetben azonnali szorongásos választ provokál, akár az adott szituációboz kötött pánikroham formájában. A személy felismeri, hogy félelme túlzott vagy észszerütlen, igyekszik ezeket a helyzeteket elkerïlni, illetve, ha ez nem lehetséges, csak intenziv szorongással vagy szenvedéssel viseli el" [2]. A klinikai gyakorlatban az intenzív félelem nagyfokú hasonlóságot mutat más szorongásos kórképek tüneteivel (remegés, gombócérzés a torokban, fokozott verítékezés, pánikroham). A szociális szorongás jellegzetességei közé tartozik még az alacsony önértékelés $[3,4]$, az alacsony önhatékonyság, a magas szintü önkritika és a mások véleményétől való nagyfokú függőoség. Az ilyen személyek leginkább attól tartanak, hogy megalázó helyzetbe kerülhetnek, vagy mások rossz véleményt alakítanak ki róluk, amit természetesen megpróbálnak elkerülni. A félelem áthatja a társas viselkedés lényegében valamennyi szféráját, előfordul, hogy heves, debilizáló vizsgaszorongás, „leblokkolás” miatt a szociális fóbiás személyek a képességeiknél rosszabb teljesítményt nyújtanak az iskolában vagy a munkahelyükön [3-8].
A szociális szorongás kontinuumként fogható fel, a szubklinikus félénkségtől kezdve a több helyzetben megnyilvánuló gátlásosságon keresztül az intenzív szorongással jellemezhető szociális fóbiáig, amelynek extrém formája az elkerülő személyiségzavar. Magas szintű krónikusság, distressz és funkcionális hanyatlás jellemzi, amely súlyosan károsíthatja a családi, baráti és munkakapcsolatokat. Ebben központi szerepet játszik a DSM-5 definícióban is szereplő negatív megítéléstól való félelem. Az érintett személy épp ezért nem kér segítséget, hiszen legnagyobb félelme épp az, hogy az emberek negatívan ítélik meg: gyengébbnek, rosszabb képességúnek vagy alacsonyabb rendűnek látják $[2,3,5-8]$.

A szociális fóbia a klinikai tapasztalatok szerint nagyfokú szenvedéssel jár: szövődményei között gyakoriak a hangulatzavarok (major depresszió $48 \%$ ), továbbá jellemző az alkoholizmus (48\%), az evészavarok (42\%) és a drogfüggőség (29\%) [1, 9-11]. Ha a szociális szorongás krónikussá válik, a személy igyekszik elkerülni a társas helyzeteket, és ez akár tartós munkaképtelenséghez is vezethet [2-6]. A szociális fóbia felismerése és pszichoterápiás kezelése ezért nemcsak önmagában, hanem a komorbid megbetegedések megelőzése érdekében is fontos.

\section{A szociális szorongás kognitín modellje}

A kognitív modellek szerint a szorongás mindig valamilyen valós vagy vélt veszélyhelyzetre adott reakció, szociális fóbiában a megalázás, megszégyenülés, illetve mások negatív véleménye vagy az attól való félelem jelenti ezt a veszélyt $[2,3,5-8,12-14]$. A szociális fóbiát jellemző, indokolatlan és túlzott mértékű szociális szorongás abból fakad, hogy a személy önmaga szociális helyzetét és értékét túlságosan alacsonyra, másokét viszont túlságosan magasra értékeli. Clark és Wells modelljében $[5,6,8]$ a negatív megítéléstől való félelem kulcsfontosságú a szociális szorongás ördögi körében (1. ábra). Az érintett egyén folyamatosan figyeli környezete reakcióit, másokról alkotott „elképzelései” mind arról szólnak, hogy a többiek őt elítélik vagy lenézik. Az egyébként átlagosnak tekinthető társas helyzetekben aktiválódó diszfunkcionális feltevéseik hatására a szociális fóbiások a szituáció jelentését félreértelmezik, extrém negatívan értékelik. Előzetes élményeik és/vagy veleszületett viselkedési diszpozíciók nyomán feltételezik, hogy társas helyzetben veszélybe kerülnek és elutasításban lesz részük teljesítményük, megjelenésük vagy viselkedésük miatt, például nem fognak tudni megszólalni, ostobának fogják őket tartani. Ez extrém mértékú szorongást indukál és szomatikus (például torokgombócérzés, elpirulás), valamint viselkedésbeli reakciókhoz (például passzivitás) vezet, amelyek további szorongás forrásaivá válhatnak. A folyamat további jellemzője, hogy a társas helyzetben az érintett személy figyelme elsösorban önmagára irányul annak érdekében, hogy minél jobb benyomást gyakoroljon a másikra. Így kevésbé tud figyelni beszélgetôpartnerére, 


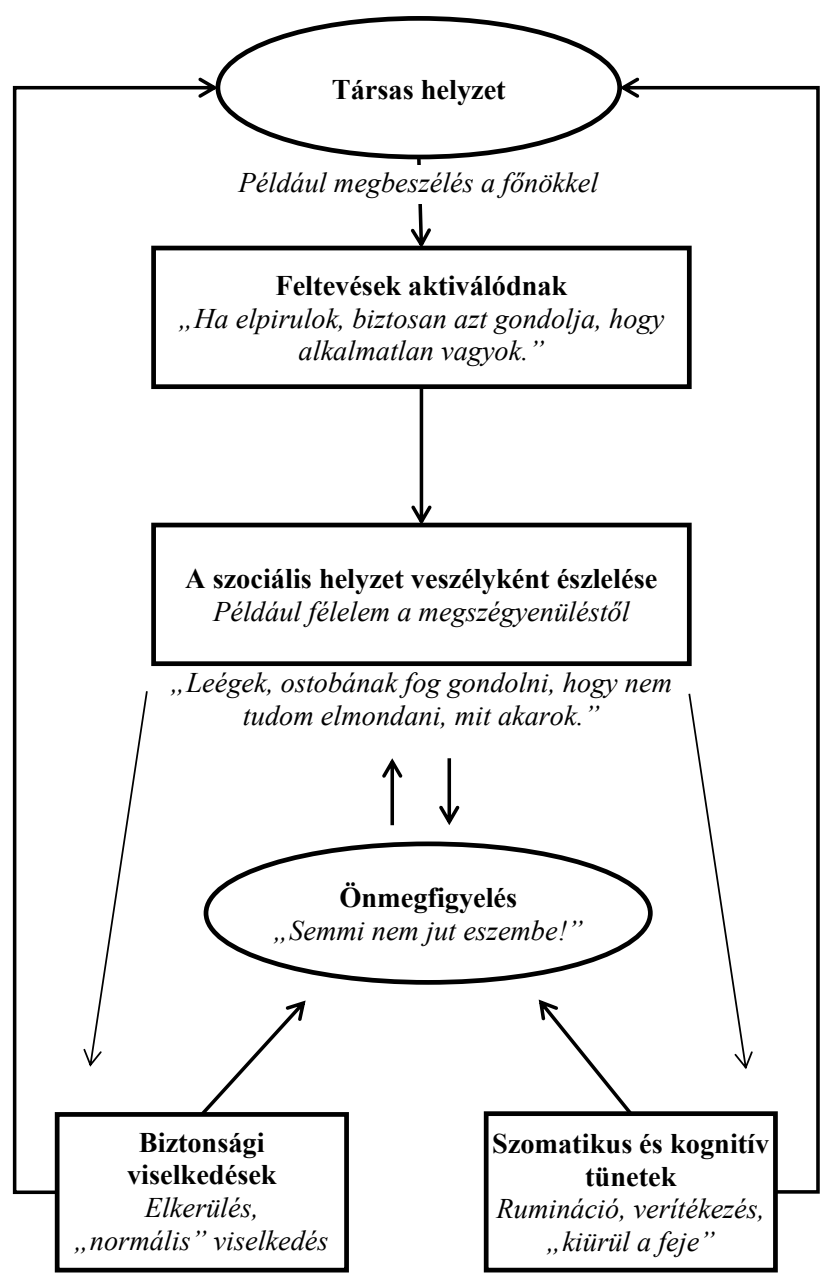

1. ábra

A szociális fóbia kognitív modellje Clark és Wells nyomán [5,
$6,8]$

érdektelennek tűnhet, ami hasonló viszonyulást vált ki a másikból - így elutasítástól való aggodalma tényleg beigazolódik $[4,12,15]$. A félelem a negatív megítéléstől tehát mind percepciós (önfigyelés), mind kognitív szinten (félreértelmezések) központi jelentőségű a szociális szorongás fennmaradásában.

\section{A „Félelem a negativ megitéléstôl” kérdöív-FÉLNE}

Watson és Friend dolgozták ki az eredeti Félelem a negatív megitéléstől (FÉLNE) kérdőívet 1969-ben. Ez 30 állításból áll, melyek a személy azon félelmeire vonatkoznak, hogy öt bolondnak nézik, rossz benyomást kelt másokban, illetve negatívan ítélik meg [16]. Már az 1980-as években felmerült, hogy a 30 tétel túl hosszú, a kérdések alig érzékelhető különbséggel ismétlődnek. $\mathrm{Az}$ eredeti változatot Leary [17] lerövidítette 12 tételre (Brief Fear of Negative Evaluation Scale - BFNE, magyarul FÉLNE-12), azonban hazánkban ez a rövidített változat nem terjedt el. Rodebaugh és mtsai [18] 2004-es összefoglaló cikkükben megerősítő faktoranalízis alkal- mazásával arra a megállapításra jutottak, hogy a kérdőív 12 tételes változatának használata, illetve a dichotóm változók helyett a Likert-skála alkalmazása hatékonyabb a diagnosztikában, mint az eredeti kérdőív. Továbbá, a Likert-skála elősegítheti a terápiás hatékonyság pontosabb követését. A faktoranalízis alapján a 30 tételes FÉLNE és a rövidített változat, a FÉLNE-12 itemei is két faktorra illeszkedtek aszerint, hogy egyenes („Gyakran aggódom, hogy valami rosszat mondok vagy teszek") vagy fordított állításként fogalmazták meg őket („Az sem zavar, ba tudom, hogy az embereknek kedvezôtlen benyomásuk van rólam”). Eszerint a faktorok inkább szemantikai, semmint tartalmi különbséget mutatnak [18].

Későbbi kutatások azt is kimutatták [15, 19-24], hogy a fordított tételek értelmezése nehézséget okoz és növeli a feszültséget, így az alacsony iskolai végzettségüeknél, továbbá épp a szorongással küzdő célcsoportnál torzítja az eredményeket $[15,24]$. Nagy mintán végzett $(\mathrm{n}=$ 1427 [19], n = 1009 [25]) kutatások is alátámasztották, hogy a legrövidebb, nyolctételes változat (FÉLNE-8) ugyanolyan hatékonysággal használható, mint a 12 vagy 30 itemes kérdőívek, noha ezekben a vizsgálatokban csak kényelmi mintát használtak.

A negatív megítéléstől való félelem vizsgálatára a magyar szakirodalomban elérhető mérőeszköz a Megmérettetés Kérdőívként ismert Fear of Negative Evaluation Scale (FNE), amely azonban kevéssé terjedt el, talán épp a hosszúsága és redundáns jellege miatt [26].

\section{Célkituzés}

A negatív megítéléstől való félelem a szociális fóbia diagnózisának egyik vezető kritériuma, és sok más mentális zavar kialakulásában is fontos szerepe van, ezért felismerése és a többi szorongásos állapottól való elkülönítése kulcsfontosságú és preventív jellegú az egészségügyi ellátás különböző szintjein. Ehhez validált, megbízható és rövid idő alatt felvehető mérőeszközre van szükség. Célunk, hogy a nemzetközileg bevált FÉLNE-30 kérdooív és rövidített változatainak magyar adaptációját elvégezzük.

\section{Hipotézisek}

A fentiek [15, 18-24] alapján feltételezzük:

1. A FÉLNE-30 kérdőív megfelelő belső validitással rendelkezik, amely a rövidítés hatására sem változik lényegesen a FÉLNE-12 és a FÉLNE-8 kérdőíveknél.

2. Mindhárom Félelem a negatív megitéléstől (FÉLNE30, FÉLNE-12, FÉLNE-8) kérdőív megfelelő külső validitással rendelkezik, azaz pozitívan korrelál a negatív szociális kogníciók gyakoriságával (SCQ_gyak), szubjektíven megélt intenzitásukkal (SCQ_int) és a szorongás erősségével (BSZL). Feltételezésünk szerint, minél alacsonyabb az önértékelés (RSES), annál intenzívebb a személy félelme a negatív megítéléstől. 
3. A FÉLNE-8, az eredeti 30 tételes kérdőívhez hasonlóan, megbízhatóan elkülöníti a szociális fóbiás csoportot az egyéb pszichés megbetegedésektôl [18, $20]$. Továbbá nem változik a múködése az életkor, a nem, az iskolai végzettség és a szocioökonómiai státusz függvényében az eredeti kérdőívhez képest, azaz a FÉLNE-30 és a FÉLNE-8 megegyező tendenciát mutatnak a fenti független változókkal való interakcióban $[19,25]$.

\section{Módszer}

\section{Mintavétel és résztvevók}

A vizsgálatba 255 fớt vontunk be intézményünk pszichoterápiás szakambulanciáján 2012-2016 között megjelenő páciensek közül, akik elsősorban szorongásos és depressziós panaszokkal jelentkeztek. A betegek az állapotfelmérő beszélgetés részeként beleegyező nyilatkozattal ellátott kérdőívcsomagot töltöttek ki, így a vizsgálatban való részvétel minden esetben önkéntes volt. Beválasztási kritériumok: 18-65 életév, pszichiátriai diagnózis a BNO alapján és a kérdőívek hiánytalan kitöltése. A szelekciós kritériumok figyelembevételével 139 nó $(54,5 \%)$ és 116 férfi $(45,5 \%)$ adatait elemeztük. Az átlagéletkor 32,9 év (18-59 év közöttiek, SD = 10,4l év). Az iskolai végzettség szerinti megoszlás országos szinten nem reprezentatív, 4,7\% $(\mathrm{n}=12)$ alapfokú, $51 \%(\mathrm{n}=$ $130)$ középfokú, 43,5\% ( $\mathrm{n}=111)$ felsőfokú végzettséggel rendelkezik. A vizsgálati személyek családi állapot szerinti megoszlása: egyedülálló $53,7 \%(\mathrm{n}=137)$, párkapcsolatban él 18\% $(\mathrm{n}=46)$, házasságban él 19,2\% $(\mathrm{n}=$ $49)$, elvált $6,3 \%(\mathrm{n}=16)$, özvegy $0,8 \%(\mathrm{n}=2)$. A minta többsége aktív dolgozó, 47,5\% ( $\mathrm{n}=121)$, az egyetemista/tanuló $23,1 \%(\mathrm{n}=59)$ és a munkanélküli/rokkant/ nyugdíjas személyek aránya $16,5 \%(\mathrm{n}=42)$. A vizsgálati személyek diagnosztikai kategóriák (BNO-10) szerinti megoszlását az 1. táblázat mutatja.

\section{Vizsgálati eljárás, vizsgálati eszközök}

Félelem a negatí megitéléstôl kérdối (FÉLNE-30) [26]. Kidolgozása Watson és Friend [16] nevéhez füződik és a szociális szorongás felmérésére szolgáló, leggyakrabban használt kérdőív, 30 tételből áll. A kérdőív egyenes és fordított dichotóm tételeiról a személynek el kell dönteni, hogy igaznak vagy hamisnak tartja-e magára nézve azokat.

Röviditett Félelem a negatín megitéléstöl (FÉLNE-12) kérdő́í [17]. Az eredeti mérőeszköz rövidített, 12 tételes változata, amelyben Leary ötfokozatú Likert-skálát használt. Jelen kutatásban dichotóm változókat alkalmaztunk az eredeti kérdőívvel való könnyebb összehasonlítás kedvéért.

Félelem a negativ megitéléstől kérdöív egyenes állitások (FÉLNE-8) [15]. A Röpiditett Félelem a negatín megitéléstôl kérdőív fordított tételek nélküli, 8 itemes, változa-
1. táblázat |A minta diagnóziscsoportok (BNO-10) szerinti megoszlása

\begin{tabular}{lc}
\hline Diagnóziscsoportok & Megoszlás \\
\hline $\begin{array}{l}\text { Szociális fóbia (önálló és kevert) (F40.10.) } \\
\text { Hangulatzavar (fóként depressziós epizód) } \\
\text { (F32-F38) }\end{array}$ & 49 fó \\
$\begin{array}{l}\text { Egyéb szorongásos rendellenességek (F41) } \\
\text { Súlyos stressz által kiváltott reakció és } \\
\text { alkalmazkodási rendellenességek (F43) }\end{array}$ & 62 fó \\
$\begin{array}{l}\text { Egyéb neurotikus stresszhez társuló zavarok } \\
\text { (F40-F49: F41.F43. F40.10 nélkül) }\end{array}$ & 55 fó \\
$\begin{array}{l}\text { Egyéb mentális zavarok (F10-F19, F50-F69) } \\
\text { Sine morbo }\end{array}$ & 20 fó \\
n. a. & 18 fó \\
\hline Összesen & 2 fó \\
\hline
\end{tabular}

ta, amely Weeks és mtsai [15] vizsgálatai alapján ugyanolyan hatékony a szociális fóbia és a negatív megítéléstől való félelem súlyosságának megítélésére, mint az eredeti 30 itemes változat. Az eredeti verzióval szemben jelen kutatásban Likert-skálák alkalmazása helyett dichotóm változók szerepelnek.

Rosenberg Önértékelési Skála (RSES) [27]. 10 tételes kérdőív a kompetenciára és elfogadásra vonatkozó állításokat tartalmaz, amelyeket négyfokozatú, 0 -3-ig terjedő Likert-skálán értékelnek a vizsgálati személyek, ahol a magasabb pontszámok a magasabb önértékelést jelzik.

Beck Szorongás Leltár (BSZL) [26]. 21 tételből álló, önbecslésen alapuló mérőeszköz, a kitöltőnek 0-3 között kell értékelnie, hogy a felsorolt tünetek milyen mértékben zavarták az elmúlt hét során. Így a szorongás egyes tüneteinek meglétéről és súlyosságáról is információkat kaphatunk. A kérdőív magas belső konzisztenciával bír.

Szociális Kogniciók Kérdöív (SCQ) [26]. Az eredeti változatot Wells és mtsai [28] a negatív hiedelmek és gondolatok azonosítására dolgozták ki. A negatív gondolatok gyakorisága skála a szociális szorongás három aspektusának elkülönítésére alkalmas: negatív hiedelmek az énről; kudarctól való félelem teljesítményhelyzetben és félelem a szorongás látható jeleitől; félelem a negatív megítéléstôl és a figyelem felkeltésétól. Az egyes skálák és alskálák megbízhatósági szintjei magasak $(\alpha=0,72 ; \alpha=$ $\left.0,84, \alpha=0,81 ; \alpha_{\mathrm{SCQ}}=0,79\right)[29]$.

A kutatást az illetékes etikai bizottság engedélyével végeztük (SE TUKEB 194/2012).

\section{Statisztikai eljárás}

A statisztikai elemzéseket IBM SPSS Statistics 23 programmal végeztük, a tesztek belső validitásának becslésére Cronbach- $\alpha$-mutatókat, a külső validitás vizsgálatára korrelációkat elemeztünk. A Félelem a negativ megitéléstől kérdő́ív három változatának összehasonlítására az egyes diagnóziscsoportokban egyszempontú variancia- 
analízist (one-way ANOVA) alkalmaztunk. Annak vizsgálatára, hogy az egyéb háttérváltozók szerinti csoportbontásban mutat-e eltérést a rövidített változat az eredeti kérdőívhez képest, ismételt méréses varianciaanalízist (repeated measures ANOVA) végeztünk. A validitásvizsgálat alátámasztására a megerősítő faktoranalízist a Statistica 13.2 szoftverrel végeztük.

\section{Eredmények}

\section{A FÉLNE-30 és a röviditett kérdöívek belsö validitása}

A FÉLNE kérdőívek Cronbach- $\alpha$-értéke mindhárom (a 30, a 12 és a 8 tételes) változatnál magasnak bizonyult $(0,929 ; 0,877 ; 0,837)$, azaz a FÉLNE-12 és a FÉLNE-8 kérdőív belső validitása a rövidítés hatására jelentősen nem változott. A külső validitás vizsgálatára alkalmazott tesztek megbízhatósága szintén magas $\left(\alpha_{\mathrm{BSZL}}=0,906\right.$; $\alpha_{\text {SCQ_gy }}=0,951 ; \alpha_{\text {SCQ_h }}=0,959 ; \alpha_{\text {SCQ_negh }}=0,859$; $\left.\alpha_{\text {SCQ_teljfél }}=0,763 ; \alpha_{\text {SCQ_negfél }}=0,762 ; \alpha_{\text {RSES }}=0,874\right)$.

A maximum likelihood és generalized least squares módszerekkel végzett megerősítő faktoranalízis alapján a FÉLNE-30 tételei illeszkednek a Rodebaugh és mtsai [18] tanulmányában megállapított kétfaktoros modellre (egyenes és fordított állítások szerinti bontás). Az illesz- kedés szintje megfelelő, de nem kiváló $\left(\chi^{2}(404)=\right.$ 819,$324 ; \mathrm{p}<0,001 ; \mathrm{RMSAE}=0,0663 ; \mathrm{GFI}=0,817$; AGFI $=0,789)$. A FÉLNE-12 tételei kiválóan illeszkednek $\left(\chi^{2}(53)=111,46 ; \mathrm{p}<0,001 ; \operatorname{RMSAE}=0,0522\right.$; GFI $=0,929 ;$ AGFI $=0,895)$. Az FÉLNE-8 szintén kiválóan illeszkedik az egyfaktoros modellre $\left(\chi^{2}(20)=\right.$ 35,$8494 ; \mathrm{p}=0,016 ; \mathrm{RMSAE}=0,0595 ; \mathrm{GFI}=0,964$; $\mathrm{AGFI}=0,935)$.

\section{Negativ megitéléstôl való félelem, negativ szociális kogniciók és alacsony önértékelés}

A FÉLNE-30, FÉLNE-12 és FÉLNE-8 is közepesen erős, fordított irányú szignifikáns együttjárást mutat az önértékeléssel (RSES) és pozitívan korrelál az általános szorongást mérő Beck Szorongás Leltárral (BSZL). Erős pozitív korrelációt találtunk a negatív megítéléstől való félelemmel (SCQ_negfél) és a negatív szociális kogníciók gyakoriságával (SCQ_gyak), mérsékelt együttjárást ezek szubjektíven megélt intenzitásával (SCQ_int), minden esetben $\mathrm{p}<0,001$ szignifikanciaszinten (2. táblázat). Eredményeink szerint tehát mindhárom FÉLNE kérdőív külső validitása magas, a legrövidebb, mindössze nyolctételes FÉLNE-8 hasonló validitásmutatókkal rendelkezik, mint a hosszabb változatok.

2. táblázat | A Félelem a negatív megítéléstől (FÉLNE) kérdőív három verziójának külső validitásvizsgálata

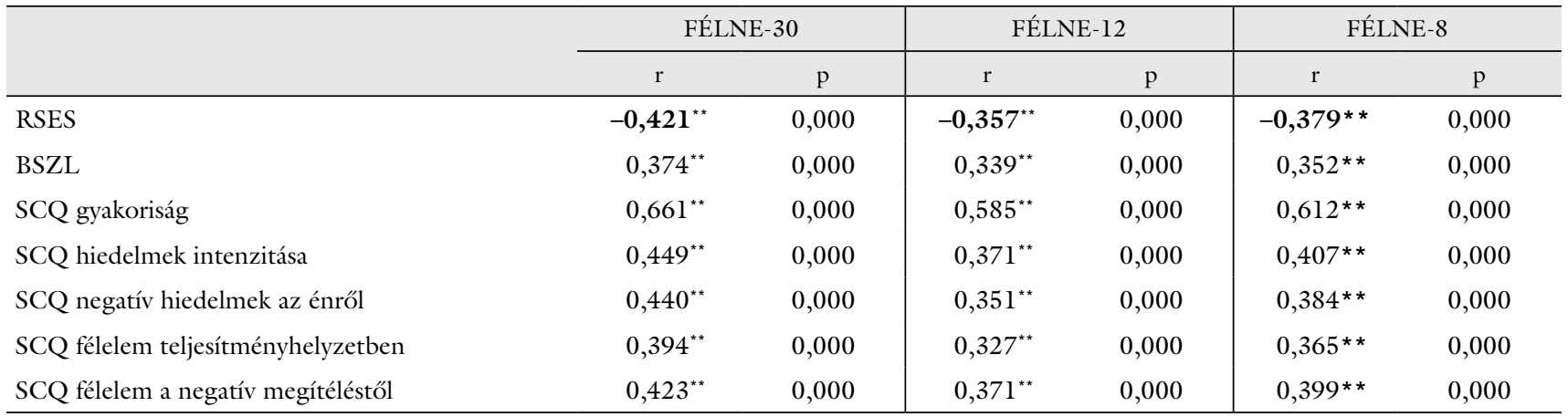

${ }^{*} \mathrm{p}<0,005 ;{ }^{* *} \mathrm{p}<0,0001$

3. táblázat |A Félelem a negatív megítéléstől (FÉLNE) kérdőív három változatán a diagnosztikai csoportok pontszámai (a szóródási mutató az átlag standard hibája)

\begin{tabular}{|c|c|c|c|c|c|c|c|c|c|}
\hline & \multicolumn{3}{|c|}{ FÉLNE-30 } & \multicolumn{3}{|c|}{ FÉLNE-12 } & \multicolumn{3}{|c|}{ FÉLNE-8 } \\
\hline & Átlag & Szórás & $\mathrm{p}$ & Átlag & Szórás & $\mathrm{p}$ & Átlag & Szórás & $\mathrm{p}$ \\
\hline SAD & 23,90 & 0,75 & - & 10,53 & 0,31 & - & 6,88 & 0,24 & - \\
\hline F3 & 16,80 * & 1,11 & $<0,001^{*}$ & $6,90 *$ & 0,54 & $<0,001 *$ & 4,42 * & 0,39 & $<0,001$ * \\
\hline $\mathrm{F} 4$ & 18,24 & 0,73 & $<0,001^{*}$ & 7,93 & 0,35 & $<0,001^{*}$ & $4,96^{*}$ & 0,26 & $<0,001$ * \\
\hline Egyéb & 17,89 * & 1,89 & 0,066 & 7,61 * & 0,89 & 0,052 & $5,00 *$ & 0,56 & 0,048 * \\
\hline SM & 11,60 * & 2,42 & 0,005 & $4,80^{*}$ & 1,23 & $0,009^{*}$ & 2,20 * & 0,94 & $0,006^{*}$ \\
\hline
\end{tabular}

*Post hoc Dunett's T3 alapján SAD-hoz viszonyítva $\mathrm{p}<0,005$.

Egyéb = egyéb mentális zavarok (F10-F19, F50-F69); F3 = hangulatzavar, depressziós epizód (F32-38); F4 = egyéb neurotikus stresszhez társuló zavarok (F40-F49 F40.10 nélkül); SAD = szociális fóbia (önálló és kevert) (F40.10); SM = sine morbo 


\section{A FÉLNE-8 kérdöí}

Az egyes diagnóziscsoportok nagysága (1. táblázat) és a csoportokban elért pontszámok szórása a FÉLNE kérdóív 30, 12 és 8 tételes változataiban lényeges különbséget mutat a Levine-próba alapján, így a pontszámok öszszehasonlításakor Dunett's T3 post hoc próbát alkalmaztunk a torzítások kiküszöbölésére. A FÉLNE-30 $(\mathrm{F}(4)=7,328 ; \mathrm{p}<0,001)$, FÉLNE-12 $(\mathrm{F}(4)=7,582$; $\mathrm{p}<0,0001)$ és a FÉLNE-8 $(\mathrm{F}(4)=7,816 ; \mathrm{p}<0,001)$ egyaránt szignifikáns különbségeket jelez a diagnosztikai csoportok szerinti bontásban (3. táblázat). Mindhárom FÉLNE kérdőíven a szociális fóbiával diagnosztizáltak szignifikánsan magasabb pontszámot mutattak, mint a hangulatzavarral, illetve az egyéb, neurotikus stresszhez társuló zavarokkal diagnosztizált csoport. A FÉLNE-30 és a FÉLNE-12 változatoknál az egyéb mentális betegségekkel diagnosztizáltak és a szociális fóbiás csoport között a különbség csupán tendenciaszerú. Egyedül a FÉLNE-8 esetében mutatkozott szignifikáns különbség a szociális fóbiás és az összes többi diagnosztikai csoport között, a szociális fóbiás csoport szignifikánsan magasabb átlagpontszámot ért el. Az elért pontszámok átlagát és a Dunett's T3 post hoc szerinti különbségeket a 3. táblázat mutatja.

Ismételt méréses varianciaanalízis alapján a FÉLNE kérdőív három változata közül egyik sem mutat eltérő tendenciát a nem $\left(\mathrm{F}_{\text {TESZTxNEM }}(2,186)=0,601 ; \mathrm{p}=\right.$ $0,549)$, iskolai végzettség $\mathrm{F}_{\text {TESZTxISK }}(4,374)=0,365 ; \mathrm{p}=$ $0,833)$, családi állapot $\left(\mathrm{F}_{\text {TESZTxCSÁLL }}(8,374)=1,817 ; \mathrm{p}=\right.$ $0,072)$ és életkor $\left(\mathrm{F}_{\text {TESZTxKOR }}(6,374)=1,363 ; \mathrm{p}=0,228\right)$ független mintás változók szerinti bontásban.

\section{Megbeszélés}

A Félelem a negatív megítéléstől kérdőív belső validitására vonatkozó első hipotézisünk beigazolódott, a Cronbach- $\alpha$ értéke a mérőeszköz mindhárom verziója esetén 0,8 feletti értéket mutatott. Az eredeti FÉLNE-30 kérdőív $\alpha=0,929$ értéke alátámasztja a kritikát $[15,17-$ 25], miszerint a kérdőív egyes állításai redundánsak, ugyanazt mérik, ezért lehet és érdemes rövidíteni a skálát.

Második hipotézisünk nagyrészt beigazolódott, amely a negatív megítéléstől való félelem, a negatív szociális kogníciók és alacsony önértékelés együttjárására vonatkozott. A külső validitás vizsgálata során a FÉLNE kérdőívek és az önértékelés (RSES) közötti közepesen erős, fordított összefüggés összhangban van mind a klinikai tapasztalatokkal, mind a szakirodalommal $[3,5]$. Noha a korreláció alapján nem dönthető el az ok-okozati összefüggés, feltételezhető, hogy minél inkább jellemzi a személyt a mások negatív véleményétől való félelem, annál alacsonyabb az önértékelése. Megfordítva, az is lehetséges, hogy minél alacsonyabb az önértékelés, annál több negatív kogníció, illetve hiedelem aktiválódik, ami szorongást keltő hatású.
A szociális szorongás és a szociális kogníciók gyakorisága közötti összefüggés erős (2. táblázat), meglepő viszont, hogy az SCQ-skála negatív megítéléstől való félelem dimenziójával csak közepes mértékű az összefüggés. Ennek hátterében az állhat, hogy míg az SCQ a negatív megítéléstől való félelem érzelmi aspektusát ragadja meg inkább, addig a FÉLNE-skálák, fóként a rövidített verziók, a kognitív dimenziót helyezik fókuszba.

Az általános szorongásszint (BSZL, 2. táblázat) szintén közepes összefüggést mutatott a FÉLNE különböző változataival, bár ezek az összefüggések minden esetben gyengébbek, mint az RSES-sel (alacsony önértékeléssel) vagy az SCQ-val (szociális kogníciókkal) mért együttjárás. Ez megerősíti azt, hogy a negatív megítéléstől való félelem a szociális szorongás speciális aspektusa, amely kevésbé jellemző más szorongásos kórképekre, bár a fizikai tünetek (például: reszketés, szédülés, gombócérzés a torokban) megtévesztésig hasonlóak lehetnek.

Végül vizsgálatunk a szakirodalomhoz hasonlóan [18, 20] igazolta, hogy a FÉLNE kérdőív mindhárom változata megbízhatóan elkülöníti a szociális fóbiás csoportot az egyéb pszichés megbetegedésekkel küzdők csoportjától. Ez támogatja a szociális fóbia kognitív modelljének azt az állítását [5-8], miszerint az indokolatlan és túlzott mértékű szorongás abból fakad, hogy a személy önmaga szociális helyzetét és értékét túlságosan alacsonyra, másokét viszont túlságosan magasra értékeli, és attól tart, hogy megkritizálják, valamint lenézik. A szorongásos megbetegedések különbséget mutatnak a rájuk jellemző kogníciók tartalmában [30]: pánikbetegségnél ez az azonnali fizikai megsemmisülésre vonatkozik (például szívinfarktustól való félelem), hipochondriánál súlyos testi betegségre (például a jövőben bekövetkező daganatos betegség), poszttraumás állapotokban pedig arra, hogy a katasztrófa bármikor megismétlődhet (például sehol sincs biztonság). A depresszióban jelentkező lehangoltság mögött meghúzódó negatív kogníciók tartalma (például értéktelenség, kilátástalanság) alapján szintén jól elkülöníthető a szociális szorongástól [30].

A többi diagnosztikai csoporttól való legmegbízhatóbb elkülönítést a legrövidebb változat, a FÉLNE-8 adta, azaz szignifikáns különbséget egyedül itt találtunk a szociális fóbiás és a többi betegcsoport eredménye között (3. táblázat). Ennek hátterében az állhat, hogy a FÉLNE-30 és a FÉLNE-12 számos fordított állítást, kettős tagadást tartalmaz, amelyek nehezen érthetők és félrevezetőek lehetnek a kitöltő személy számára, például „nem feltétlenül izgat, ha nem járok másnak a kedvében" $[15,19-24]$. Ezzel szemben a mindössze nyolc egyenes állítást tartalmazó FÉLNE-8 kérdőív megfogalmazásai, úgy túnik, megbízhatóan elkülönítik a szociális fóbiás csoportot az egyéb pszichés megbetegedésektől, ami a kérdőív jó reliabilitására és szenzitivitására utal. 


\begin{tabular}{|c|c|c|c|c|c|c|}
\hline & & $\begin{array}{c}\text { (Szinte) } \\
\text { Soha }\end{array}$ & Néha & Rendszerint & Gyakran & $\begin{array}{l}\text { (Szinte) } \\
\text { Mindig }\end{array}$ \\
\hline 1. & $\begin{array}{l}\text { Nyugtalanít, hogy mit gondolnak rólam az emberek, még akkor is, ha } \\
\text { tudom, hogy ez egyáltalán nem számít. }\end{array}$ & 1 & 2 & 3 & 4 & 5 \\
\hline 2. & Gyakran tartok attól, hogy mások észreveszik a gyenge pontjaimat. & 1 & 2 & 3 & 4 & 5 \\
\hline 3. & Félek attól, hogy mások nem fognak egyetérteni velem. & 1 & 2 & 3 & 4 & 5 \\
\hline 4. & Félek attól, hogy mások megjegyzéseket fognak rám tenni. & 1 & 2 & 3 & 4 & 5 \\
\hline 5 . & Amikor beszélgetek valakivel, nyugtalanít, vajon mit gondolhat rólam. & 1 & 2 & 3 & 4 & 5 \\
\hline 6. & $\begin{array}{l}\text { Általában aggodalmaskodni szoktam amiatt, hogy milyen benyomást } \\
\text { keltek. }\end{array}$ & 1 & 2 & 3 & 4 & 5 \\
\hline 7. & $\begin{array}{l}\text { Időnként úgy érzem, túl sokat foglalkozom azzal, hogy mások mit } \\
\text { gondolnak rólam. }\end{array}$ & 1 & 2 & 3 & 4 & 5 \\
\hline 8. & Gyakran aggódom amiatt, hogy valami rosszat mondok vagy teszek. & 1 & 2 & 3 & 4 & 5 \\
\hline
\end{tabular}

Alátámasztást nyert az is, hogy a rövidített verziók nem mutatnak eltérő tendenciát a FÉLNE-30 eredeti változatához képest a nem, korcsoport, iskolai végzettség és szocioökonómiai státusz szerinti bontásban.

\section{Következtetések}

A szociális szorongás a harmadik leggyakoribb pszichés megbetegedés, ami a lakosság 13-15\%-át érinti. Nagyfokú komorbiditást mutat a hangulatzavarokkal, az alkoholfogyasztással, valamint az evészavarokkal, ezért felismerése és kezelése hozzájárul e másodlagos megbetegedések remissziójához. A többi szorongásos kórképtôl leginkább a jellegzetes kognitív tünetek alapján lehet elkülöníteni, amelyek a mások negatív megítélésétól való félelem, az alacsony önértékelés és alacsony önhatékonyság, a magas szintú önkritika és a mások véleményétool való nagyfokú függőoség $[2,3,5-8,12-14,30]$. Kutatásunk a szociális szorongás felmérésére szolgáló, nemzetközileg legismertebb méróeszköz, a „Félelem a negatív megítéléstől" kérdőív hazai adaptálására irányult, amely a szociális fóbia központi mechanizmusát teszi könnyen felismerhetővé. A FÉLNE-30 kérdőív nyolctételes rövid változata könnyen érthetô, megbízható, magas belső és megfelelő külső validitással rendelkezik, amely az egészségügyi ellátás különféle szintjein könnyen alkalmazható. Vizsgálatunk alapján egyértelműnek tûnik, hogy a FÉLNE-8 (4. táblázat) alkalmazása elősegítheti a számos pszichés megbetegedés hátterét jelentő, alacsony önértékelésből fakadó szociális szorongás felismerését, valamint a páciensek adekvát pszichoterápiás ellátás felé irányítását.

Anyagi támogatás: A közlemény megírása, illetve a kutatómunka anyagi támogatásban nem részesült.

Szerzői munkamegosztás: P-F. D. fordította a kérdőívet, tervezte meg a tanulmány alapjául szolgáló vizsgálatot, biztosította a szakmai hátteret, koordinálta a kérdő́ivek felvételét és kiértékelését, részt vett a bevezetés, a Megbeszélés és a Következtetések megfogalmazásában, és áttekintette a kézirat többi részét. K. Sz. végezte az adatelemzést, a szakirodalom-kutatást és -feldolgozást, a kézirat megfogalmazását. A cikk végleges változatát mindkét szerző elolvasta és jóváhagyta.

Érdekeltségek: A szerző́knek nincsenek érdekeltségeik.

\section{Köszönetnyilvánítás}

Szeretnénk kifejezni köszönetünket és hálánkat a résztvevőknek a kérdőívek kitöltéséért.

\section{Irodalom}

[1] Kessler RC, Petukhova M, Sampson NA, et al. Twelve-month and lifetime prevalence and lifetime morbid risk of anxiety and mood disorders in the United States. Int J Methods Psychiatr Res. 2012; 21 : 169-184.

[2] American Psychiatric Association. Diagnostic and statistical manual of mental disorders (5th ed.). [DSM-5 Referencia kézikönyv a DSM-5 diagnosztikai kritériumaihoz]. Oriold és Társai Kiadó és Szolgáltató Kft., Budapest, 2013; pp. 194-195. [Hungarian]

[3] Iancu I, Bodner E, Ben-Zion IZ. Self esteem, dependency, selfefficacy and self-criticism in social anxiety disorder. Compr Psychiatry. 2015 ; 58: 165-171.

[4] Fennell MJ. Cognitive therapy in the treatment of low self-esteem. Adv Psychiatr Treat. 1998; 4: 296-304.

[5] Perczel-Forintos D. Cognitive behaviour therapy of social phobia. In: Perczel-Forintos D, Mórotz K. (eds.) Cognitive behavior therapy. [A szociális fóbia kognitív viselkedésterápiája. In: Perczel-Forintos D, Mórotz K. (szerk.) Kognitív viselkedésterápia.] Medicina Könyvkiadó, Budapest, 2010; pp. 337-368. [Hungarian]

[6] Clark MD. A cognitive perspective on social phobia. In: Crozier WR, Alden LE. (eds.) International handbook of social anxiety: concepts, research, and interventions relating to the self and shyness. Wiley, New York, 2001; pp. 405-430.

[7] Heimberg RG. A new model to facilitate individualized case con ceptualization and treatment of social phobia: An examination and reaction to Moscovitch's model. Cogn Behav Pract. 2009; 16: $135-141$ 
[8] Clark D, Wells AA. Cognitive model of social phobia. In: Heimberg RG, et al. (ed.) Social phobia. The Guilford Press, London, 1995; pp. 69-93.

[9] Adams GC, Balbuena L, Meng XF, et al. When social anxiety and depression go together: A population study of comorbidity and associated consequences. J Affect Disord. 2016; 206: 48-54.

[10] Buckner JD, Schmidt NB, Schmidt AR, et al. Specificity of social anxiety disorder as a risk factor for alcohol and cannabis dependence. J Psychiatr Res. 2008; 42: 230-293.

[11] Swinbourne J, Hunt C, Abbott M, et al. The comorbidity between eating disorders and anxiety disorders: prevalence in an eating disorder sample and anxiety disorder sample. Aust $\mathrm{N} \mathrm{Z} \mathrm{J}$ Psychiatry. 2012; 46: 118-131.

[12] Rapee RM, Heimberg RG. A cognitive-behavioral model of anxiety in social phobia. Behav Res Ther. 1997; 35: 741-756.

[13] Kizilcik IN, Gregory B, Baillie AJ, et al. An empirical analysis of Moscovitch's reconceptualised model of social anxiety: How is it different from fear of negative evaluation? J Anxiety Disord. 2016; 37: 64-70.

[14] Moscovitch DA. What is the core fear in social phobia? A new model to facilitate individualised case conceptualization and treatment. Cogn Behav Pract. 2009; 16: 123-134.

[15] Weeks JW, Heimberg RG, Hart TA, et al. Empirical validation and psychometric evaluation of the Brief Fear of Negative Evaluation Scale in patients with social anxiety disorder. Psychol Assess. 2005 ; 17: 179-190.

[16] Watson D, Friend R. Measurement of social-evaluative anxiety. J Consult Clin Psychol. 1969; 33: 448-457.

[17] Leary MR. A brief version of the Fear of Negative Evaluation Scale. Pers Soc Psychol Bull., 1983; 9: 371-375.

[18] Rodebaugh TL, Woods CM, Thissen DM, et al. More information from fewer questions: the factor structure and item properties of the original and the brief Fear of Negative Evaluation Scale. Psychol Assess. 2004; 16: 169-181.

[19] Liu L, Lowel PA. Examination of the Brief Fear of Negative Evaluation Scale-Version 2 and the Brief Fear of Negative Evaluation Scale-Straightforward Items factor structure in a sample of U.S. college students. Can J Sch Psychol. 2016; 31: 122-138.

[20] Collins KA, Westra HA, Dozois DJ, et al. The validity of the brief version of the Fear of Negative Evaluation Scale. J Anxiety Disord. $2005 ; 19$ : 345-359.

[21] Carleton RN, McCreary DR, Norton PJ, et al. Brief Fear of Negative Evaluation Scale-revised. Depress Anxiety. 2006; 23: $297-$ 303.
[22] Carleton RN, Collimore KC, Asmundson GJ. Social anxiety and fear of negative evaluation: Construct validity of the BFNE-II. J Anxiety Disord. 2007; 21: 131-141.

[23] Carleton RN, Collimore KC, McCabe RE, et al. Addressing revisions to the Brief Fear of Negative Evaluation Scale: Measuring fear of negative evaluation across anxiety and mood disorders. J Anxiety Disord. 2011; 25: 822-828.

[24] Harpole JK, Levinson CA, Woods CM, et al. Assessing the straightforwardly-worded Brief Fear of Negative Evaluation Scale for differential item functioning across gender and ethnicity. J Psychopathol Behav Assess. 2015; 37: 306-317.

[25] Wei J, Zhang C, Li Y, et al. Psychometric properties of the Chinese version of the Fear of Negative Evaluation Scale-Brief (BFNE) and the BFNE-Straightforward for middle school students. PLoS ONE. 2015; 10: e0115948.

[26] Perzel-Forintos D, Kiss Zs, Ajtay Gy. (eds.) Questionnaires and inventories in clinical psychology. [Kérdőívek, becslőskálák a klinikai pszichológiában]. Semmelweis Kiadó, Budapest, 2012. [Hungarian]

[27] Rózsa SV, Komlósi A. Psychometric analysis of Rosenberg SelfEsteem Scale: Item-wording, dimensionality and item characteristics. [A Rosenberg Önbecsülés Skála pszichometriai jellemzói: A pozitívan és negatívan megfogalmazott tételek múködésének sajátosságai.] Pszichológia. 2014; 34: 149-174. [Hungarian]

[28] Wells A, Stopa L, Clark DM. The Social Cognitions Questionnaire. 1993. In: Lockett $H$. Is social anxiety co-morbid with psychosis the same as social anxiety as a primary diagnosis? An exploratory comparison of schemas, thoughts and social anxiety related imagery. Doctoral Thesis. East Anglia, 2011; p. 179.

[29] Wells A. Cognitive theory and models of anxiety: an introduction. In: Cognitive therapy of anxiety disorders: A practice manual and conceptual guide. Wiley, Chichester, 1997; pp. 3-20.

[30] Perczel-Forintos D. Basics of cognitive therapy. In: PerczelForintos D, Mórotz K. (eds.) Cogni-tive behavior therapy. [A kognitív sze $\neg$ mlélet alapvonalai. In: Perczel-Forintos D, Mórotz K. (szerk.) Kognitív viselkedésterápia.] Medicina Könyvkiadó, Budapest, 2010; pp. 189-214. [Hungarian]

(Perczel-Forintos Dóra dr., Budapest, Tömő u. 25-29., 1083 e-mail: perczel-forintos.dora@med.semmelweis-univ.hu)

\section{"Dixi et salvari animam meam" (Megmondtam és ezzel megkönnyebbült a lelkem.)}

